\title{
Discretionary powers of the public administration in providing the NPO state registration services
}

\author{
Viktor Eduardovich Gatsolati ${ }^{11}$, Alexander Borisovich Zelentsov ${ }^{1}$, and Bulat \\ Umerzhanovich Seitkhozhin ${ }^{2}$ \\ ${ }^{1}$ RUDN University of Russia, Law Institute, Department of Administrative and Financial Law, \\ Moscow, Russia \\ ${ }^{2}$ Scientific Research Institute of Economic and Legal Researches of Karaganda Economic University, \\ Karaganda, Kazakhstan
}

\begin{abstract}
The purpose of the research is to determine the impact of the current administrative and legal regulation of the implementation of administrative procedures for the provision of the non-profit organisation state registration services on the scope of discretionary powers of the public administration in the provision of this service. The methodological basis of the research is created by modern philosophical, general-scientific and special-scientific methods of cognition including dialectical, logical, formal-legal, systemic and statistical methods, as well as analysis, description, synthesis and interpretation. The research results were the conclusions from the analysis of the administrative and legal regulation of administrative procedures for the provision of the non-profit organisation state registration services. Thus, in particular, the discrepancy between a separate provision of the administrative regulation on the provision of the non-profit association state registration services with the current federal legislation was identified and a proposal to amend it was formulated. In addition, it was concluded that the detailed regulation at the sub-legal level of the procedure for the implementation of administrative procedures for the provision of public services has a negative impact on the scope of discretionary powers of public administration bodies. The research novelty lies in the adopted methodological approach to the analysis of the overseas experience in legal regulation of the implementation of administrative procedures by public administration bodies and the conduct of a comparative legal study of regulation of the implementation of administrative procedures for the provision of public services in Russia and in the European Union member states.
\end{abstract}

Keywords: public service, administrative procedure, administrative regulations, administrative discretion

\section{Introduction}

${ }^{1}$ Corresponding author: gatsolati.viktor@gmail.com 
The trend of detailed regulation of the administrative procedures, which leads to an excessive reduction in the scope of discretionary powers of public administration, continues to actively gain momentum in our country. This trend will inevitably lead to a decrease in the public administration efficiency.

One of the forms of activities of the public administration is public services [1], the varieties of which include the provision of the non-profit organisation (NPO) state registration services as legal entities.

The implementation by the public administration of administrative procedures for the provision of public services in modern Russia is regulated by a large number of bylaws of the executive authorities, administrative regulations. These regulatory documents regulate in detail the procedure for exercising the powers assigned to the public administration to provide services to individuals. Such detailing virtually deprives the public administration of discretionary powers; this is quite clearly manifested in the provision of the NPO state registration services.

The scientific hypothesis of the research is based on the assumption that the current administrative and legal regulation of the procedure for carrying out administrative procedures for the provision of the NPO state registration services in Russia leads to an excessive decrease in the scope of the discretionary powers of the public administration.

\section{Method}

The methodological basis of the research is created by modern philosophical, general-scientific and special-scientific methods of cognition including dialectical, logical, formal-legal, systemic and statistical methods, as well as analysis, description, synthesis and interpretation. Special focus was put on the comparative legal research method which made it possible to analyse regulating the implementation of administrative procedures for the provision of public services in Russia and the European Union member states.

\section{$3 \quad$ Results and discussion}

State registration of NPOs in Russia is carried out through the consistent implementation of the appropriate administrative procedures with the adoption of an administrative ruling. By using the classification proposed by a number of authors, we can talk about administrative procedures for the provision of public services [2].

The domestic science of administrative law by the administrative procedure understands administrative procedural rules that determine the procedure for the implementation by public administration bodies of the powers assigned to them in order to resolve a legal case or perform an administrative function. Administrative procedures regulate the external power relations of public administration bodies, and according to Khazanov, "are more important, since their implementation affects the constitutional rights and freedoms of citizens" [3]. The implementation of state registration of NPOs by the authorised bodies of public administration allows citizens to exercise their constitutional right to association.

The majority of Russian scientists note the importance and indispensability of the institution of administrative procedures and are convinced that the foundations of their implementation should be recorded at the level of federal legislation. Starilov calls the absence of legal regulation of administrative procedures virtually the only problem of administrative law not solved at the legislative level [4]. However, the author does not indicate any specific negative consequences of the problem.

Administrative procedures in our country are regulated by subordinate regulatory documents of public administration bodies, administrative regulations. Administrative 
regulations are legal instruments of administration adopted in order to establish intra-organisational rules for the activities of public administration, as well as the administrative procedure implementation requirements [5].

Domestic scientists identify such goals and objectives of issuing administrative regulations as enhancing the quality of management activities of public administration bodies [6], optimising the activities of public administration bodies [5] and limiting arbitrary administrative discretion [7].

The limits and expediency of administrative discretion are the most pressing issues in studying it by domestic scientists. Agamagomedova speaks about the need to determine the optimal level of discretion when public administration bodies exercise their powers [8]. Milshin notes that granting the right to discretion to a public administration body should meet the criterion of expediency, as well as be controlled by state bodies and public entities [9].

Some authors point to the risk of an excessive and unlimited expansion of the limits of administrative discretion in our country $[9,10]$ which can lead to the creation of conditions that stimulate corruption risks [11].

In the author's opinion, researchers' theses about an increase in corruption risks while expanding the limits of administrative discretion are unsubstantiated. The author shares the position of Pudelk, who pointed out that decisions made by officials of public administration bodies are subject to control by the judiciary and therefore, decisions on the basis of discretion themselves do not carry any corruption risks [12]. Violation of anti-corruption legislation entails the cancellation of the decision and bringing the official to legal responsibility.

Despite concerns and identified shortcomings of decisions made on the basis of discretion, almost all domestic scientists agree on the need to endow public administration bodies with the freedom to choose options for administrative decisions in order to improve the public administration efficiency [13].

The legal basis for administrative discretion is created by the permissive principle of legal regulation, according to which a public administration body and its officials are the bearers of only those rights that are directly provided for by law [14]. Consequently, the discretionary power of the public administration body should be enshrined in the same law which gives it the right to make the appropriate administrative decision.

The powers of the Ministry of Justice of the Russian Federation in the implementation of administrative procedures for the provision of the NPO state registration services are enshrined in the federal legal provisions.

The wording of Art. 23.1 of the Law on Non-Profit Organisations, Article 23 of the Law on Public Associations which establish a list of grounds for a possible refusal to register an NPO, the public administration body has the right, at its discretion, to make a decision to either refuse state registration or suspend it.

However, clause 50 of the Administrative Regulations approved by Order of the Ministry of Justice dated December 30, 2011 No. 455 establishing the standard and procedure for the provision of the relevant public service contains an exhaustive list of grounds for refusing state registration of an NPO. This list almost completely coincides with the grounds, the existence of which, in accordance with federal legislation, gives the authorised body of public administration the right, at its discretion, to make a decision to either refuse state registration or suspend it.

Thus, the specified provisions of the delegated legislation issued by the Ministry of Justice are in conflict with the federal legislation.

In order to implement the principle of the rule of law, on the basis of clause 2 of article 4 of the Constitution of the Russian Federation, it is necessary to make appropriate changes to the administrative regulations for the implementation of state registration of NPOs. 
Clause 50 (of the part of it that establishes the grounds for refusing the state registration of a public association) of the Administrative Regulations for the provision of public services by the Ministry of Justice of the Russian Federation for making a decision on the non-profit organisation state registration shall be stated as follows:

" 50 . If there are grounds for a possible rejection of the state registration of a non-profit organisation established by federal legislation, a public association may either be denied the state registration or a decision to suspend it may be made. In the same case, if the name of a public association offends morality, national or religious feelings of citizens, then the public association should be denied the state registration."

Naturally, by exercising the existing right to discretion, an official of a public administration body should correlate the adopted management decision with the public interest, which, in the opinion of Tikhomirov, is the standard of administrative discretion [14].

The given example demonstrates that a consequence of the detailed regulation of the implementation of administrative procedures for the provision of public services by bylaws is a decrease in the scope of discretionary powers of the public administration. The decline in the quality of public services is one of the negative consequences of such administrative and legal regulation of the legal relations in question.

The administrative legislation of the EU Member States offers an alternative to the detailed regulation of administrative procedures - laws that establish general procedural rules for the public administration activities [15].

Examples of laws of the named category are:

Law of the Republic of Austria No. 51 of 1991 "Administrative Procedures".

Federal Republic of Germany Law of 1976 "Administrative Procedures".

Law of the Kingdom of Spain No. 39 of October 1, 2015.

Law of the French Republic of April 12, 2000 "Kights of Citizens in their Relations with State Bodies."

It should be noted that these laws are applied only in the absence of detailed regulation of the same object by another special regulatory instrument [16].

The administrative legislation of the European Union countries establishes only the bases and general principles for the implementation of administrative procedures for the provision of the NPO state registration services retaining the public administration's right to make administrative decisions at their own discretion. For example, part 3 of Article 47 of the Legislative Decree of the President of the Italian Republic No. 117 of July 3, 2017, reserves the right of the State Administration of the Unified National Register of NPOs to invite the applicant to bring the documents submitted by them in accordance with the established requirements, if any violations are found.

An analysis of the rules governing the procedure for the implementation of administrative procedures for the provision of the NPO state registration services in the Russian Federation and in the European Union Member States allows us to highlight the difference in the level of legal regulation. The EU Member States consolidate the foundations and basic principles for the implementation of administrative procedures at the legislative level. Administrative procedures in Russia are carried out on the basis of the provisions enshrined in by-laws (administrative regulations) issued by authorised public administration bodies. According to the author, the administrative and legal regulation of public relations existing in our country and arising in the implementation of administrative procedures for the provision of public services leaves no room for discretion.

\section{Conclusion}


The reduction in the scope of discretionary powers of the public administration in the implementation of administrative procedures for the provision of public services in Russia is due to the absence of a general Law on Administrative Procedures and the existence of a large number of by-laws that regulate in detail the procedure for carrying out those procedures. According to the author, the lack of an appropriate level of discretion in the public administration negatively affects the efficiency of administrative activities and the quality of public services provided.

It is possible to solve that problem by referring to the experience of the EU Member States, in the system of legal regulation of which there is no detailed regulation of the implementation of administrative procedures for the provision of public services at the subordinate level, and the foundations and basic principles of their implementation are legislatively enshrined.

The research was carried out with the financial support of the Russian Foundation for Basic Research in the framework of the scientific project No. 20-311-90031

\section{References}

1. A.B. Zelentsov, O.A. Yastrebov, Newsl. St. Petersburg Univ. Pravo 10(4), 645 (2019). https://doi.org/10.21638/spbu14.2019.402

2. A.I. Stakhov, I.A. Nesterenko, Admin. Law and Proc. 4, 37-42 (2012)

3. S.D. Khazanov, Rus. Leg. J. 1(37), 58-63(2003)

4. Yu.N. Starilov, Newsl. Voronezh State Univ. Ser.: Law 3(22), 20-28 (2015)

5. O.S. Rogacheva, Admin. Law and Process, 6, 48-52 (2013)

6. V.F. Lomakina, Proc. Instit. State and Law Rus. Acad. Sci. 5, 93-101 (2016)

7. A.F. Nozdrachev, Legisl. and Econ. 8, 5-41 (2011)

8. S.A. Agamagomedova, Admin. Law and Process, 1, 49-52 (2020). https://doi.org/10.18572/2071-1166-2020-1-49-52

9. Yu.N. Milshin, Admin. Law and Process, 12, 43-45 (2019)

10. E.A. Chaban, Admin. Law and Process, 11, 64-69 (2013)

11. A. Grishko, A. Burchikhin, Crime and Punish. 6, 6-7 (2013)

12. J. Pudelka, Newsl. St. Petersburg Univ. Right 4, 434-451 (2017). https://doi.org/10.21638/11701/spbu14.2017.406

13. Yu.P. Solovey, Admin. Law and Process, 7, 5-15 (2018)

14. Yu.A. Tikhomirov. J. Rus. Law, 4, 70-79 (2000)

15. K.V. Davydov, Newsl. O.E. Kutafin Univ. (M. State Law Acad.), 1(41), 99-109 (2018). https://doi.org/10.17803/2311-5998.2018.41.1.099-109

16. J. Marku, Administrativnye akty i protsedury Rossii i drugikh gosudarstv Evropy [Administrative Documents and Procedures of Russia and other European States], in T.Ja. Khabrieva, J. Marku (eds.), Administrative Procedures and Control in the Context of European Experience (Statut, Moscow, 2011) 